\title{
Quantitative analysis of the root system of Avicennia alba based on the pipe model theory
}

\author{
Chadtip Rodtassana, Sasitorn Poungparn* \\ Department of Botany, Faculty of Science, Chulalongkorn University, 254 Phayathai Road, \\ Bangkok 10330 Thailand
}

${ }^{*}$ Corresponding author, e-mail: sasitorn.p@ chula.ac.th

Received 30 May 2012

Accepted 27 Oct 2012

\begin{abstract}
Reliable estimation of the root biomass is essential to quantify the total amount and proportion of the carbon sink of a forest, especially for mangrove forests that exhibit various extensive root systems. One way to estimate root biomass is to use a quantitative root-system measurement based on the pipe model theory (PMT), which assumes that the total cross-sectional area of roots is identical among the different root-size classes for an individual plant. The PMT states that the cross-sectional area of the tree stem at the ground level supports a fixed total weight of roots. Therefore, estimation of the root weight of a tree is possible from measuring the stem diameter if that species conforms to the model. Using a water pump, the whole root system of three Avicennia alba trees, a pioneer species commonly dominating the mud flats and river edges of secondary mangrove forests in Thailand, were excavated. The living roots were sorted into diameter classes and their individual dry weights obtained. A significant inverse linear relationship was obtained between the root diameter and the number of roots of each sampled tree, with the regression slopes not statistically different from -2.0 (range -2.19 to -2.83 for the three trees) conforming to the PMT. The ratio between the total root weight and the basal area of the stem at the ground level ranged from $0.0340-0.0389$, which is smaller and larger than that for Sonneratia caseolaris and Xylocarpus granatum, respectively, two other mangrove tree species previously reported to conform to the PMT.
\end{abstract}

KEYWORDS: estimated root number, mangrove forest, root weight

\section{INTRODUCTION}

Forests constitute a major component of the global carbon reserves in different ecosystems, and greatly influence the lives of other organisms including humans. Mangrove forests are an ecologically and potentially economically important intertidal plant community distributed along subtropical and tropical coasts. The forest is being depleted by conversion to agriculture, aquaculture, tourism, urban development, and overexploitation ${ }^{1,2}$. Besides, sea-level rise is supposed to be the biggest threat to mangrove ecosystems in the future ${ }^{3}$.

The root systems of mangroves typically show physiological and morphological adaptations to sustain and survive in the non-firm and waterlogged soils, which are usually of an anaerobic condition ${ }^{4}$. A special feature of mangroves is that they allocate a large amount of biomass to roots, in terms of the ratio of the above-ground $(T)$ and root $(R)$ biomass, with a $T / R$ ratio typically in the range of $2.0-3.0^{5-7}$. Therefore, mangrove trees are described as a bottomheavy tree form ${ }^{8}$.

Avicennia alba Blume is a pioneer species that typically dominates the open areas of river edges or mud flats. It sustained accretion under the mangrove fringe, and thus influenced the geomorphology with a relation to coastal erosion ${ }^{9}$. Its root system is fairly complex, being derived from up to four types of roots, namely pneumatophores and cable, feeding and anchor roots ${ }^{10}$. Cable roots run horizontally and radially for several meters from the tree, whilst pneumatophores grow vertically upwards from the cable roots to expose their tips above the soil and water line and into the air. Feeding roots arise from the pneumatophore roots at just below the soil surface and grow horizontally, whilst anchor roots grow vertically down often to over $1 \mathrm{~m}$ depth. Thus the root system is complex and difficult to estimate in its entirety.

Quantitative studies on the root biomass and so the $T / R$ ratio of trees, and especially mangrove trees, are scarce ${ }^{6,11}$, due to difficulty of such studies in the field ${ }^{11-13}$, such as the weight of the wood and muddy soil conditions from which the extensive but heterogeneous root system must be extracted (in contrast to the above-ground parts). In the last decade, some studies have reported a simple method for rootbiomass estimation via the quantitative analysis of 
the root system of mangroves ${ }^{14,15}$ based on the pipe model theory (PMT) ${ }^{16}$ and the static model of plant form.

According to the PMT, a tree is composed of a unit of pipes connecting the leaves, branches, stems, and roots. The cross-sectional area of the pipes gathering in the stem at ground level supports the total root weight of a tree. Thus the root weight of an individual tree can be estimated from the basal area of its stem at ground level, once the species has been established to conform to the PMT. From the quantitative analysis of the root system, performed by evaluating the distribution of root diameters, it was proposed that a root system of a tree would conform to the PMT when the total cross-sectional areas of all the root sizes are identical ${ }^{16}$.

Given the above, the aim of this study was to quantitatively analyse the pneumatophore root system of A. alba based on the PMT to ascertain that this does indeed comply with the PMT. In order to test if the root system conforms to the PMT, a quantitative analysis was performed on the distribution of root diameters. We hypothesized that the total cross-sectional area of all sizes of roots are equal. In addition, the A. alba root system was compared with the reported root systems of Xylocarpus granatum Koenig ${ }^{14}$ and Sonneratia caseolaris ${ }^{15}$, two mangrove tree species that comply with the PMT. The application of the PMT is discussed in terms of the potential advantage for root weight estimation in mangrove species.

\section{MATERIALS AND METHODS}

The study site was located at a secondary mangrove forest on an estuary of the Trat river $\left(12^{\circ} 12^{\prime} \mathrm{N}\right.$, $102^{\circ} 33^{\prime}$ E), Trat province, Thailand. This area has been managed by the Mangrove Forest Development Centre No. 1 of the Department of Marine and Coastal Resources, Thailand. A study plot of $300 \mathrm{~m}^{2}$ on the edge of the river where S. caseolaris and A. alba were dominant was selected and the number of trees was recorded, along with their diameter at breast height (DBH). Within the study plot, the total tree density was 2133 stems/ha, with a DBH range and mean size of $4.5-15.5 \mathrm{~cm}$ and $12.2 \mathrm{~cm}$.

Three A. alba trees were then selected from the river edge in the study plot. We selected isolating tree to prevent the interfering root system of neighbouring trees. The tree dimensions, including the DBH, stem diameter at ground level $\left(D_{0}\right)$, stem diameter at $0.3 \mathrm{~m}$ height from the ground $\left(D_{0.3}\right)$, and tree height $(H)$, were measured. Then, the above-ground part was cut at the ground level using a handsaw. The whole root system was excavated using a water-pump (Honda-
WB20XT) to remove the soil surrounding the root system. All roots were washed and transported to the laboratory at the Mangrove Forest Learning and Development Centre No. 1. The living roots were visually identified in terms of their root surface, firmness, freshness, and colour ${ }^{17-19}$. The greenish parts of the pneumatophores, which were conical, were removed so as to separate them from the parts which were originally truly underground (buried under the soil), and then measured for the basal diameter and size of each individual pneumatophore piece. Each pneumatophore was then cut and separated at the points where the diameters were 5,10 , and $20 \mathrm{~mm}$. The below-ground roots were manually separated into diameter classes $(0-2,2-5,5-10,10-20,20-30,30$ $40, \ldots,>70 \mathrm{~mm})$. The roots within each diameter class were then weighed (fresh or wet weight) using an electric balance (Sartorius model TE31025). For each root size class, each of approximately $50 \mathrm{~g}$ (fresh weight) were individually accurately weighed and then oven-dried at $110^{\circ} \mathrm{C}$ to a constant weight to obtain the dry weight. It usually took 1-4 days depending on the root size. The average dry/wet weight ratio was then calculated for each root-diameter class to act as the conversion factor for converting the fresh weight to dry weight.

The volume of each individual pneumatophore was calculated from its basal diameter and height, assuming a conical shape. To estimate the volume of the below-ground roots, the dry weight of each diameter class was divided by the root specific gravity (SG) in $\mathrm{g} / \mathrm{cm}^{3}$. The $\mathrm{SG}$ of each root-diameter class was estimated from the dry weight of sub-sample root divided by its volume. To obtain the root volume, the length and diameter of sub-sample root in each diameter class was measured and converted to cylindrical volume. The total volume of roots in each diameter class was then used to calculate the number of $10 \mathrm{~cm}$ length equivalent root pieces $\left(F^{\prime}\right)$.

\section{RESULTS AND DISCUSSION}

The total root weight (below-ground plus pneumatophore weights) of the three A. alba samples ranged from $1.567-6.472 \mathrm{~kg}$ depending on the tree diameter, whilst the $T / R$ ratio ranged from 3.37-5.03 (Table 1). This is relatively high compared to that reported by Komiyama et $\mathrm{al}^{6}$ of a $T / R$ ratio of around 2.0-3.0 for some common species of mangrove forests (i.e., $R$. apiculata, $R$. mucronata, B. gymnorrhiza, S. caseolaris), and rather closer to that of 3-5 reported for upland forests. However, it is somewhat similar to the $T / R$ ratio of 4.4 for $S$. caseolaris, a mangrove tree that also produces an extensive root system with 


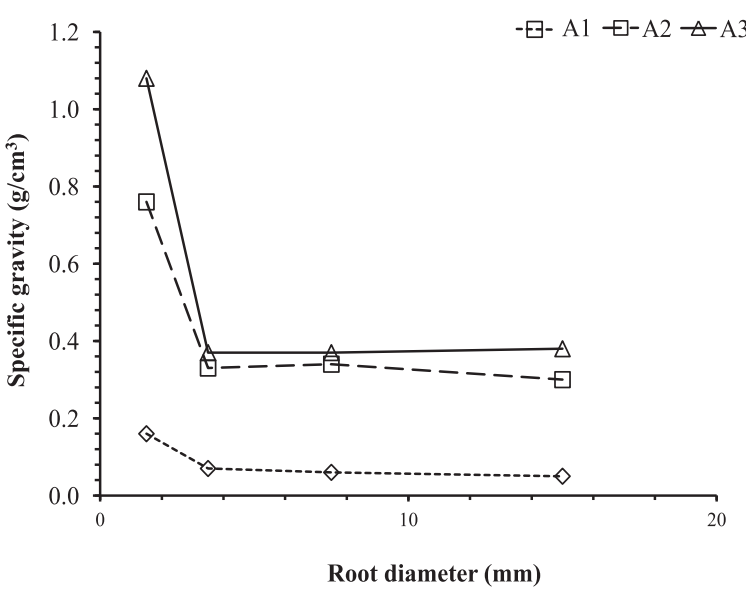

Fig. 1 The specific gravity of the roots from three A. alba trees segregated into the different root-diameter classes.

aerenchyma rich pneumatophores of low density.

The explanation for the apparently high $T / R$ ratio does not lie in a low root biomass, but rather in that root systems with pneumatophores are usually composed of a relatively low density non-woody part compared to the typically higher density woody part, i.e., stilt root of Rhizophora and the knee root of Bruguiera. A. alba naturally grows on muddy flats or along river edges that are always inundated for longer periods during each tidal cycle. As a consequence, they grow in a waterlogged soil with a more limited oxygen supply for root respiration and, in common with other mangrove species growing in anoxic soil conditions with a long inundation period, they have a special anatomical structure, the aerenchyma tissue, in their submerged roots ${ }^{10,20}$. Lawton et $\mathrm{al}^{21}$ reported that root structure of the related A. marina is composed of large air spaces in the cortex.

Indeed, the average SG of the below-ground roots of $A$. alba ranged from $0.24-0.67 \mathrm{~g} / \mathrm{cm}^{3}$. All three tree samples showed a similar negative relationship between the root SG and the root diameter, with the SG decreasing markedly and then slightly with increasing root diameters above $2 \mathrm{~mm}$ and $5 \mathrm{~mm}$ diameter, respectively (Fig. 1). In addition the root density tended to decrease with increasing tree size for all root diameter categories.

The root structure of $S$. alba is reported to have higher root porosity in the larger roots than in the smaller roots ${ }^{22}$, and so the lower SG of the larger roots likely reflects the larger volume of spongy aerenchyma filling the root tissue. In a contrast, the root SG of $X$. granatum, a mangrove tree that usually grows on the drier, less water inundated regions of the

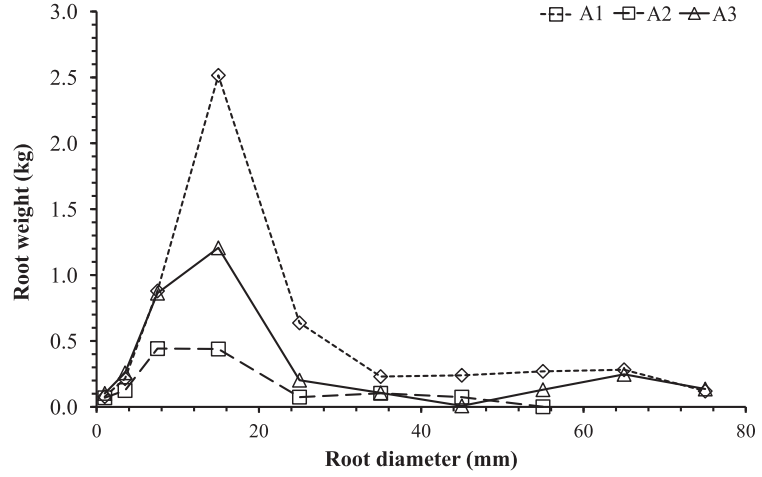

Fig. 2 Distribution of the root weight of $A$. alba trees along the different root-diameter size classes.

forest, is reported to have an increasing root SG as the root diameter increases ${ }^{14}$. Presumably, the density of aerenchyma tissue is lower in the roots of those species that principally grow in drier areas having less anaerobic soil.

The distribution of the A. alba root mass as a function of the root diameter revealed that the largest amount of root mass was found in the medium-sized roots $(10-20 \mathrm{~mm})$, accounting for $36 \%$ of the total root weight, while the smaller and larger size categories of roots were each comprised of a much smaller proportion of the total mass (Fig. 2). The abundant mass of medium-sized roots can be explained as their function of cable roots that extend horizontally from the tree trunk to sustain the tree body of A. alba on the infirm and muddy substrate.

A linear relationship between the estimated root number, as the number of $10 \mathrm{~cm}$ length equivalent root pieces $\left(F^{\prime}\right)$, and root diameter $(D)$ was obtained on a $\log -\log$ scale as $F^{\prime}=a D^{b}$, where $a$ and $b$ are constants expressing the $y$-axis intercept and slope, respectively (Fig. 3). The $F^{\prime}-D$ relationship was significant $(P<0.05)$ for all three tree samples with a relatively high correlation coefficient $\left(r^{2}\right.$ from $0.765-$ 0.800 ). The root number was negatively related to its diameter, with the regression slope varying from -2.19 to -2.83 , but these were not significantly different from -2.0 ( $t$-test, $P<0.05)$. Hence the number of roots is essentially proportional to $D^{-2}$ and related to the cross-sectional area of the roots. Consequently, the total cross-sectional areas of each size class of roots are essentially equal within an individual sample, supporting that the root system of A. alba, or at least these three samples, broadly conform to the PMT. As with the present study, the root system of six samples of $X$. granatum $^{14}$ and one sample of $S$. caseolaris $^{15}$ were also found to conform 
Table 1 Sizes, total aboveground weight ( $\left.W_{\text {above }}\right)$, belowground weight $\left(W_{\text {below }}\right)$, pneumatophore weight $\left(W_{\text {pneum }}\right)$, and root weight ( $W_{\text {root }}$ ), and the $T / R$ ratio of three samples of $A$. alba. The $T / R$ ratio was calculated from $W_{\text {above }} / W_{\text {root }}$.

\begin{tabular}{lccccccccc}
\hline Tree & $D_{0}(\mathrm{~cm})$ & $D_{0.3}(\mathrm{~cm})$ & DBH $(\mathrm{cm})$ & $H(\mathrm{~m})$ & $W_{\text {above }}(\mathrm{kg})$ & $W_{\text {below }}(\mathrm{kg})$ & $W_{\text {pneum }}(\mathrm{kg})$ & $W_{\text {root }}(\mathrm{kg})$ & $T / R$ \\
\hline A1 & 14.0 & 12.9 & 8.5 & 9.3 & 21.819 & 6.384 & 0.088 & 6.472 & 3.37 \\
A2 & 9.9 & 6.8 & 5.6 & 5.7 & 6.558 & 1.502 & 0.065 & 1.567 & 4.18 \\
A3 & 11.8 & 9.9 & 6.8 & 8.9 & 19.171 & 3.085 & 0.725 & 3.811 & 5.03 \\
\hline
\end{tabular}

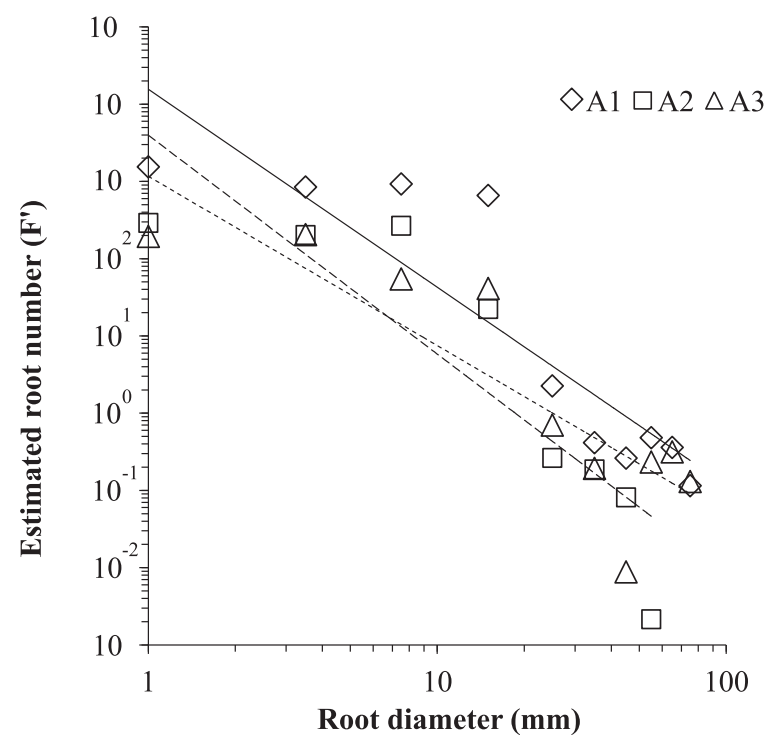

Fig. 3 Distribution of the root number $\left(F^{\prime}\right)$ along the rootdiameter classes of three A. alba samples. A significant linear regression was found for each individual tree on a logarithmic scale. The correlation coefficients $\left(r^{2}\right)$ of the regression were $0.800,0.773$, and 0.765 , respectively, for $\mathrm{A} 1, \mathrm{~A} 2$, and $\mathrm{A} 3$.

to the PMT on an individual plant basis.

According to the PMT, an individual root weight can be estimated from the basal area of the stem at ground level of a tree. In the present study, the proportional ratio between the total root weight and the basal area of the stem at the ground level of the three A. alba samples was in the range of 0.0340-0.0389, which lies in-between that derived from the single specimen of $S$. caseolaris $(0.025)^{15}$ and the average value of six $X$. granatum specimens $(0.051)^{14}$. It is remarkable that the proportional constant of $A$. alba was lower than that for $X$. granatum but higher than that for $S$. caseolaris. Nevertheless, the implication is that for a given ground stem diameter value the likely total root mass would be in the order of $X$. granatum $>$ A. alba $>$ S. caseolaris.

In conclusion, the relationship between the number of roots and their diameter showed that the total cross-sectional area of each size class of roots are essentially equal within any individual $A$. alba tree, and so supports that the root systems of $A$. alba trees likely obey the PMT on an individual basis.

Acknowledgements: We are grateful to the Thailand Research Fund for financial support. The staff of the Centre of Mangrove Forest Study and Development No. 1 at Trat, Thailand, are thanked for assistance in the field. Dr R. D. J. Butcher is thanked for help with correcting the manuscript.

\section{REFERENCES}

1. Alongi DM (2002) Present state and future of the world's mangrove forests. Environ Conservat 29, 331-49.

2. Giri C, Zhu Z, Tieszen LL, Singh A, Gillette S, Kelmelis JA (2008) Mangrove forest distributions and dynamics (1975-2005) of the tsunami-affected region of Asia. J Biogeogr 35, 519-28.

3. Giri C, Ochieng E, Tieszen LL, Zhu Z, Singh A, Loveland T, Masek J, Duke N (2011) Status and distribution of mangrove forests of the world using earth observation satellite data. Global Ecol Biogeogr 20, 154-9.

4. Hogarth JP (1999) The Biology of Mangroves, Oxford Univ Press, New York.

5. Komiyama A, Poungparn S, Kato S (2005) Common allometric equations for estimating the tree weight of mangroves. J Trop Ecol 21, 471-7.

6. Komiyama A, Ong JE, Poungparn S (2008) Allometry, biomass, and productivity of mangrove forest: A review. Aquat Bot 89, 128-37.

7. Khan MNI, Suwa R, Hagihara A (2005) Allometric relationships for estimating the aboveground phytomass and leaf area of mangrove Kandelia candel (L.) Druce trees in the Manko Wetland, Okinawa Island, Japan. Trees Struct Funct 19, 266-72.

8. Ong JE, Gong WK, Wong CH (2004) Allometry and partitioning of the mangrove, Rhizophora apiculata. Forest Ecol Manag 188, 395-408.

9. Bird ECF (1986) Mangroves and intertidal morphology in Westernport Bay, Victoria, Australia. Mar Geol 69, 251-71.

10. Tomlinson PB (1986) The Botany of Mangroves. Cambridge Univ Press, London.

11. Gong WK, Ong JE (1990) Plant biomass and nutrient 
flux in a managed mangrove forest. Estuar Coast Shelf Sci 31, 519-30.

12. Robertson AI, Dixon P (1993) Separating live and dead fine roots using colloidal silica: an example from mangrove forests. Plant Soil 157, 151-4.

13. Lugo AE, Snedaker SC (1974) The ecology of mangroves. Annu Rev Ecol Systemat 5, 39-64.

14. Poungparn S, Komiyama A, Jintana V, Piriyota S, Saengtain T, Tanapermpool P, Patanaponpaiboon P, Kato S (2002) A quantitative analysis on the root system of a mangrove, Xylocarpus granatum Koenig. Tropics 12, 35-42.

15. Poungparn S, Komiyama A, Patanaponpaiboon P, Maknual C, Sangtiean T, Kato S (2004) A quantitative analysis on root of a mangrove, Sonneratia caseolaris (L.) Engler, with reference to the pipe model. Tropics 13, 249-53.

16. Shinozaki K, Yoda K, Hozumi K, Kira T (1964) A quantitative analysis of plant form: The pipe model theory. I. Basic analysis. Japan J Ecol 14, 97-105.

17. Persson H (1978) Root dynamics in a young Scots pine stand in Central Sweden. Oikos 30, 508-19.

18. Leuschner C, Hertel D, Coners H, Büttner V (2001) Root competition between beech and oak: a hypothesis. Oecologia 126, 276-84.

19. Meinen C, Hertel D, Leuschner C (2009) Biomass and morphology of fine roots in temperate broad-leaved forests differing in tree species diversity: is there evidence of below-ground over yielding? Oecologia 161, 99-111.

20. Schweingruber FH, Börner A, Schulze E-D (2006) Atlas of Woody Plant Stems: Evolution, Structure, and Environmental Modifications, Springer, Berlin.

21. Lawton JR, Todd A, Naidoo DK (1981) Preliminanry investigation into the structure of the roots of the mangroves Avicennia marina and Bruguiera gymnorhiza in relation to ion uptake. New Phytol 88, 713-22.

22. Purnobasuki H, Suzuki M (2004) Aerenchyma formation and porosity in root of mangrove plant, Sonneratia alba (Lythraceae). J Plant Res 117, 465-72. 